УДК 532.783, 544.252.22, 538.9

DOI: $10.18384 / 2310-7251-2017-4-103-113$

\title{
EFFECT OF GRANULAR SILVER FILMS MORPHOLOGY ON THE MOLECULES ORIENTATION AND ION CONTAMINATION OF NEMATIC LIQUID CRYSTAL ${ }^{1}$
}

\section{E. Konshina, D. Shcherbinin}

Saint-Petersburg National Research University of Information Technologies, Mechanics and Optics

Kronverksky prosp. 49, Saint-Petersburg 197101, Russian Federation

Abstract. The structure of granular silver films at the interface of liquid crystal (LC) cells and their influence on LC molecule orientation and ionic contamination are examined. Granular silver films were deposited on a glass substrate covered with an ITO electrode and a-C:H thin films. The morphology structure of the silver films was changed after their annealing at $200^{\circ} \mathrm{C}$. The silver granules became spheroidal with an average diameter of $-30 \mathrm{~nm}$ and the channel area between them increased. The change in the structure of the $\mathrm{Ag}$ films led to an increase in the phase retardation and a decrease in the pretilt angle of the $\mathrm{LC}$ director from $51^{\circ}$ to $7^{\circ}$. The density of ionic impurities in the LC cell with the annealed silver film was three times more than in the LC cell with the unannealed film. The impact of the alignment of the LC molecules at the surface of the granular silver films on the intensity of the plasmonic peak and its red shift in the absorption spectra is shown.

Key words: silver film, a-C:H film, nematic liquid crystal, ionic impurities, absorption spectra.

\section{ВЛИЯНИЕ МОРФОЛОГИИ ГРАНУЛИРОВАННЫХ СЕРЕБРЯНЫХ ПЛЁНОК НА ОРИЕНТАЦИЮ МОЛЕКУЛ И ИОННОЕ ЗАГРЯЗНЕНИЕ НЕМАТИЧЕСКОГО ЖИДКОГО КРИСТАЛЛА}

\author{
Коншина Е.А., Щербинин Д.П. \\ Санкт-Петербургский национальный исследовательский университет \\ инсоормационных технологий, механики и оптики \\ 197101, Кронверкский пр. 49, Санкт-Петербург, Россия
}

Аннотация. В данной работе исследуется структура серебряных гранулированных плёнок на межфазных границах ЖК ячеек и их влияние на ориентацию молекул и ионное загрязнение ЖК. Гранулированные серебряные плёнки осаждались на стеклянные подложки покрытые электродами ITO и тонкими пленками а-С:Н. После отжига при температуре $200^{\circ} \mathrm{C}$ морфология структуры серебряных плёнок изменялась. Серебряные гранулы

\footnotetext{
Исследование выполнено в рамках гранта Министерства образования и науки Российской Федерации №3.92.2014/К и гранта РФФИ №16-02-0041 A / The work was supported by the Ministry of Education and Science of the Russian Federation (Grant No. 3.92.2014/K) and the Russian Foundation for Basic Research (Grant No. 16-02-00041 A).
}

() Коншина Е.А., Щербинин Д.П., 2017. 
принимали сфрероидную форму со средним диметром 30 нм, каналы между гранулами уширялись. Изменение структуры серебряной пленки привело к увеличению фазовой задержки в слое ЖK и уменьшению угла преднаклона директора от $51^{\circ}$ до $7^{\circ}$. Плотность ионных примесей в ЖК ячейке с отожженной серебряной плёнкой была в три раза выше, чем в ячейке с неотоженной плёнкой. Показано влияние ориентации ЖК молекул на поверхности гранулированной серебряной плёнки на интенсивность и батохромный сдвиг пика плазменного резонанса в спектрах поглощения.

Ключевые слова: серебряные плёнки, а-С:Н плёнки, нематический жидкий кристалл, ионные примеси, спектры поглощения

\section{Introduction}

Currently, the study of metallic nanostructures and liquid crystals (LC) interaction is relevant. It is important from a fundamental point of view and attracts scientist's attention due to the possibilities of practical use of such systems. Periodic metal films and liquid crystals allow to create new types of photonic devices. Plasmonic properties of metal films are sensitive to a change of the refractive index of surrounding media. LC refractive index depends on LC molecule orientation and can be controlled by an external action. The combination of periodic metal surfaces with LCs provides the possibility of tuning their plasmonic properties by an external electric field [1-3]. Metal/ LC interfaces are employed as tunable microwave and IR devices [4-6].

The orientation of LC molecules depends on Van der Waalse intermolecular forces and an anisotropic elastic interaction at interfaces with a solid surface [7]. Modern techniques of preparing thin solid films allow to control a pretilt angle and LC molecules alignment by changing a surface morphology and physicochemical properties [8-13]. Previous studies established that the orientation of LC molecules on metals surfaces depends on the properties of these materials, thickness of metal films and morphology of metal film surfaces. $\mathrm{Au}, \mathrm{Cr}$ and $\mathrm{Al}$ films were used to produce a planar orientation of LC molecules. The use of smooth silver film provides a vertical LC orientation, while relief surfaces resulted in a planar or a tilted orientation of LC molecules $[1 ; 14-18]$.

Liquid crystals are not an ideal dielectric and contain ionic impurities. Nanoparticles added in LC bulk and orienting layers on an interface affect the ionic density. The balance between the processes of ion adsorption and desorption on nanoparticles and thin film surfaces determine the ionic density in LC bulk [19-21]. Doping metal nanoparticles in LC can enhance LC conductivity [22-27]. In the case with LC display the increase of ionic conductivity is a drawback. However, LC conductivity enhancement may be used in non-display applications, such as diffuse light scattering devices [28], wave-front correctors [29] and generator of low-frequency oscillations [30].

The impact of granular silver films morphology on the orientation of molecules and ion contamination of nematic liquid crystal are discussed in this paper. We have studied how the morphology changing of granular silver films as a result of their annealing impacted on liquid crystal alignment at the interface. SEM images of the structures of granular silver films before and after annealing were compared. We measured the transmittance versus voltage curves of the LC cells with unannealed 
and annealed Ag films to compare phase retardations and the pretilt angle of director. The diffuse currents were measured in LC cells with unannealed and annealed $\mathrm{Ag}$ films at the interface to determine ionic densities. The impact of interaction of granular silver films with liquid crystal on their absorption spectra is discussed also.

\section{Experimental details}

We have examined granular silver films and plane-parallel LC cells with these films at the interface. Granular silver films were produced by thermal evaporation in a PVD 75 vacuum chamber (Kurt J. Lesker) at a residual pressure of $\sim 1,3 \times 10^{-5} \mathrm{~Pa}$ and room temperature. The silver films thickness was about $40 \mathrm{E}$ [31]. These films were deposited on glass substrates covered with ITO transparent electrode and a-C:H thin film. ITO transparent electrodes were obtained by cathode sputtering. The a-C:H insulating layers were deposited in glow discharge plasma from toluene vapor at a pressure of $2,7 \times 10^{-2} \mathrm{~Pa}$ and a room temperature. Such a-C:H layers can be used as LC alignment layers [13]. To change the structure morphology, the granular silver films were annealed at $200{ }^{\circ} \mathrm{C}$ for 20 minutes in vacuum after deposition. ITO, a-C-H and granular silver films were deposited on the LC cell surface of substrate in series. Plane-parallel LC cells were assembled from the two substrates separated by spacers. The second LC cell substrate with ITO electrode was coated with a polyimide layer to align LC molecules parallel to the interface. This layer was obtained by spin coating of the solution, followed by annealing at a temperature of $180^{\circ} \mathrm{C}$. Then the polyimide surface was rubbed in one direction. An electrically controlled LC cell with a gap of $12,5 \pm 0,5 \mu \mathrm{m}$ was filled with a nematic liquid crystal under the action of capillary forces. The nematic LC ZhK-1282 (NIOPIK, Moscow) with optical anisotropy $\Delta n=0,17$ at $632,8 \mathrm{~nm}$ wavelength, phase transition temperature $63^{\circ} \mathrm{C}$, and positive dielectric anisotropy $\Delta \varepsilon=9.9$ at a frequency of $1 \mathrm{kHz}$ was used for cells fabrication. The homogeneity of LC orientation had verified before experiments using polarized optical microspore.

The morphology features of the granular silver films were investigated by a Merlin scanning electron microscope (SEM) (Carl Zeiss). The sizes and areas of silver nanoparticles were analyzed by statistical image processing using the Toup View computer program. Spectral studies of the Ag / a-C:H / ITO structures on a glass substrate and in the LC cells were performed with an SF-56 spectrophotometer (LOMO). Nonpolarized light beam with a wave vector always perpendicular to the substrate was used to measure optical density.

To measure curves of the transmittance vs. voltage (T-V) of LC cells we used the electro optic setup comprising a laser LED with a wavelength of $650 \mathrm{~nm}$, a photo detector, a voltage generator, an oscilloscope and computer. LC cells were placed between crossed polarizers in such a way that the angle between the directions of the long axes of LC molecules and polarized light vector to be $45^{\circ}$. Sinusoidal voltage with $1 \mathrm{kHz}$ frequency was applied to the cells to measure $T-V$ curves at a wavelength of $650 \mathrm{~nm}$. Pretilt angle in LC cells are estimated using equation [32]: 


$$
R_{0}=\frac{2 \pi d n_{0}}{\lambda}\left[\frac{n_{e}}{\sqrt{n_{e}^{2} \sin ^{2} \theta_{p}+n_{o}^{2} \cos ^{2} \theta_{p}}}-1\right],
$$

$R_{0}$ is the phase retardation at initial time, $n_{o}$ and $n_{e}$ are ordinary and extraordinary refractive index, $\lambda$ - wavelength.

The contact of the liquid crystal with the granular silver film results in ionic contamination. To characterize this process a diffuse current leakage was measured after removing DC voltage applied to the cell. We used the circuitry in which a LC cell was connected in series with a resistor and voltage generator. The drop of voltage at probing resistor was measured with an oscilloscope connected in parallel to the resistor. The current in the circuit was calculated by the Ohm law. For the experiments we used a 10 $\mathrm{k} \Omega$ probing resistor. The density of the ions was evaluated as

$$
c=\frac{1}{e S d} \int_{t} i(t) d t
$$

where $e$ - elementary charge, $S$ - electrodes area, $d$ - cell gap, $i$ - measured current, $t$ - time [33].

\section{Results and discussion}

SEM images of the structures of granular silver films before $(a)$ and after annealing (b) are depicted in Figure 1.

The granules of silver films are separated by channels with a-C:H. Flat granules of $\mathrm{Ag}$ became more relief after annealing and had an almost spheroid shape with an average diameter of $\sim 30 \mathrm{~nm}$.

The filling factor was determined as the ratio of the sum of nanoparticle areas to the substrate area. The estimation showed that this factor decreased from $53 \%$ to $42 \%$ after annealing of silver films. Our study has indicated the decrease of nanoparticle dimension in the plane of the substrate and the increase of the channel area between the granules [34].

LC molecules orientation on the surfaces consisted of several materials depend on the ratio of areas, the anchoring strength and the relief of materials surface [18]. On the smooth Ag film surface LC molecules tend to align perpendicular [15]. In Figure 2 the
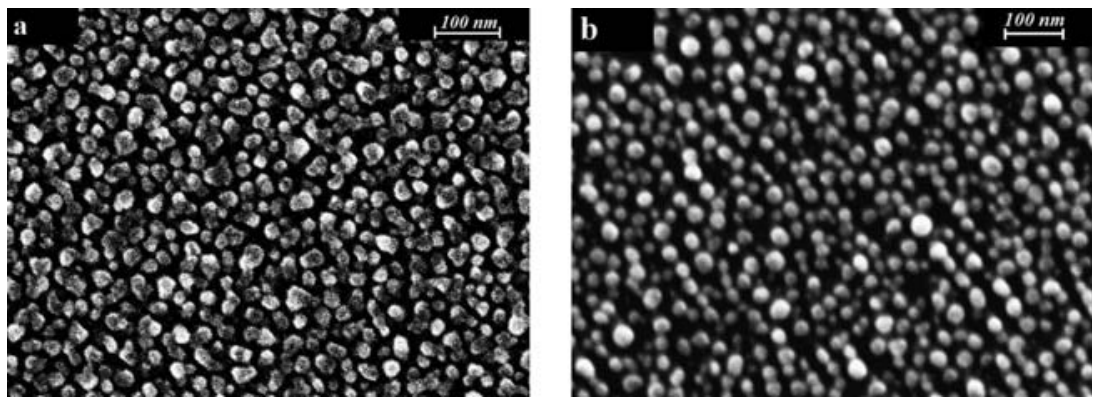

Fig. 1. SEM images of the granular silver films deposited on a-C:H/ ITO thin multilayer films on glass substrate before $(a)$ and after annealing $(b)$ at the temperature of $200^{\circ} \mathrm{C}$ in vacuum [34]. 


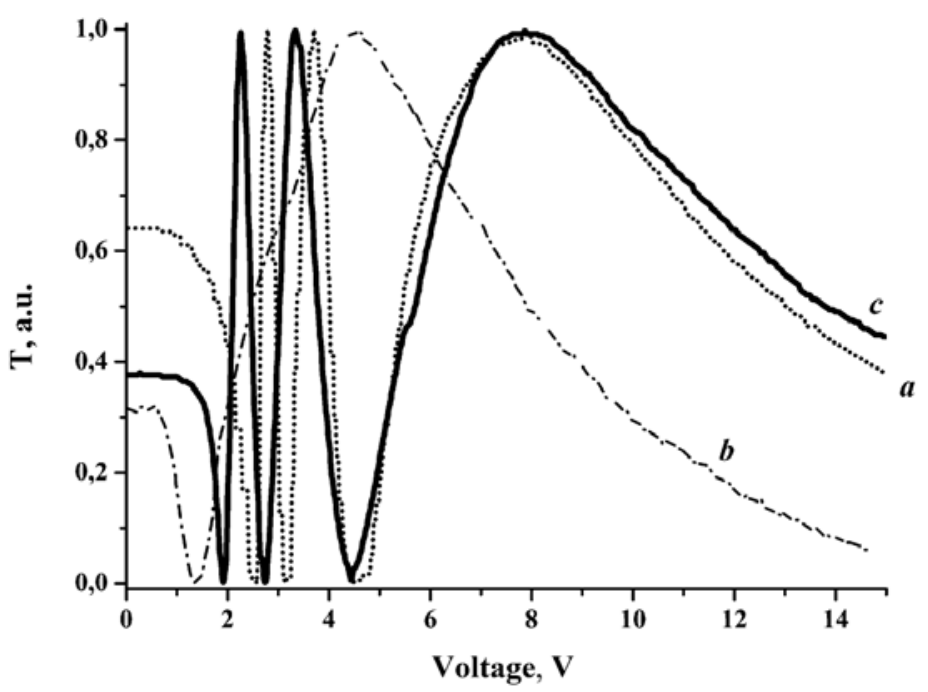

Fig. 2. Experimental T-V curves at a wavelength of $650 \mathrm{~nm}$, obtained by applying an $\mathrm{AC}$ voltage with a frequency of $1 \mathrm{kHz}$, for the planar-oriented LC cell without $\mathrm{Ag}(a)$ and hybrid cells with unannealed $(b)$ and annealed $(c)$ granular silver films on one interface of the LC cells.

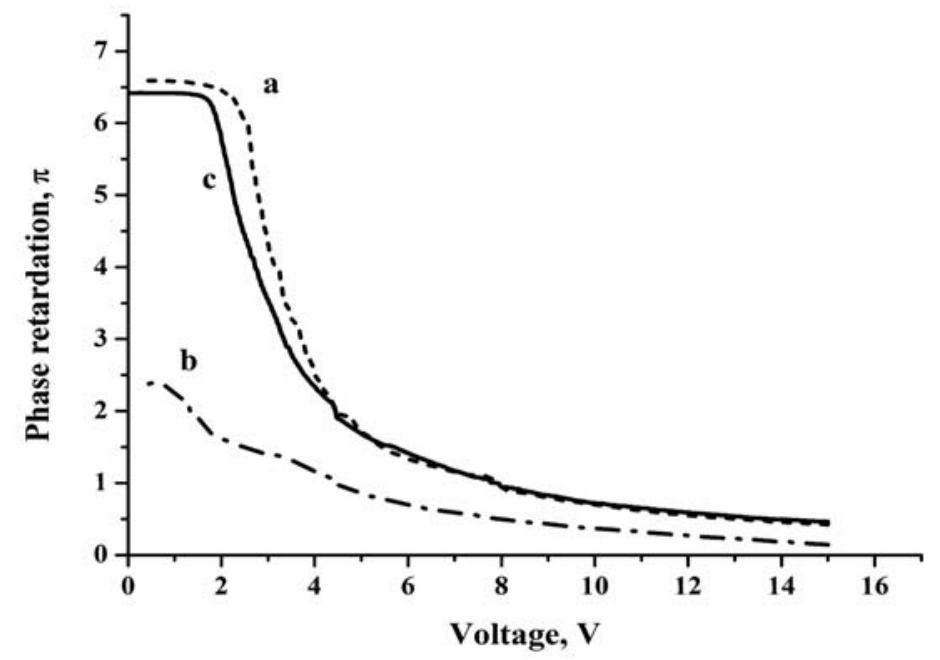

Fig. 3. Phase retardations vs. AC voltage with a frequency of $1 \mathrm{kHz}$ at a wavelength of $650 \mathrm{~nm}$ for the planar-oriented LC cell without Ag film (a) and hybrid cells with unannealed $(b)$ and annealed $(c)$ granular silver films on one interface of the LC cells.

$\mathrm{T}-\mathrm{V}$ dependences are shown at a wavelength of $650 \mathrm{~nm}$ for the planar-oriented LC cells using a-CH thin films without $\mathrm{Ag}(a)$, with unannealed $(b)$ and annealed $(c)$ granular silver films at the one interface.

$\mathrm{T}-\mathrm{V}$ curves were obtained applying sinusoidal voltage at a frequency of $1 \mathrm{kHz}$. The $\mathrm{T}-\mathrm{V}$ curves were used to calculate the phase retardation and a pretilt angle of the LC cells as was described in [31]. 
Figure 3 shows the phase retardation curves for the studied LC cells. The phase retardation curve of the hybrid LC cell with an annealed silver film at the interface differed from the curve for planar oriented LC cell with the a-C:H layers without silver film in the voltage range below $4 \mathrm{~V}$. That is due to different threshold voltages and phase retardation in initial time.

In case of the LC cell without Ag films, the phase retardation was $6,6 \pi$ and the pretilt angle was equaled to $3^{\circ}$. The phase retardations were $2,3 \pi$ and $6,4 \pi$ in the LC cells with the unannealed and annealed films respectively. The calculation of the pretilt angle from equation (1) showed that it is equal to $51^{\circ}$ in the LC cell with an unannealed Ag film. This means that the LC cell has a hybrid orientation of the LC, since the polyimide layer deposited on the opposite substrate had a pretilt angle close to zero. Thus, at the interface with the unannealed granular silver film, the LC molecules align with a pretilt angle more than $51^{\circ}$.

A pretilt angle of the LC cell with the annealed $\mathrm{Ag}$ film was near $7^{\circ}$. This means that a change in the structure of the Ag film as a result of annealing causes a planar orientation of LC molecules with a small pretilt angle at the interface. Annealing the granular films led to the diffusion of Ag atoms and small clusters in the channels. The shape and size of individual granules varied and the channels area increased (fig. 1b) as the filling factor decreased on $11 \%$. Thus, it can be concluded that the change of LC orientation as a result of the films annealing can be explained by three factors - increasing the channels area, removing silver atoms from the channels and changing the surface relief.

We have studied changes in the ion density in the LC cells with the granular silver films. fig. 4 shows the dependence of the diffusion current of ions $(I)$ on the time $(t)$ after the removal of the rectangular pulse amplitude of $20 \mathrm{~V}$ with the duration of $300 \mathrm{~ms}$ applied to the LC cells without Ag films ( $a$ ) and with unannealed (b) and annealed (c) Ag films.

The ion density in the LC cell with the annealed Ag film estimated by integrating the curves $c$ in fig. 4 was $1,8 \times 10^{16} \mathrm{~cm}^{-3}$. In the LC cell with the unannealed Ag film the ion

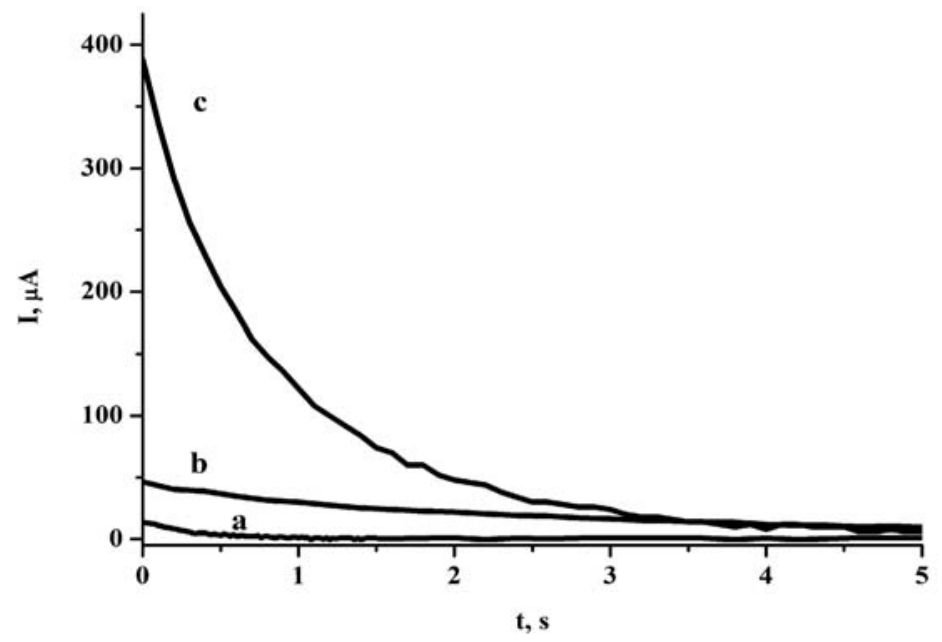

Fig. 4. Diffusion current of charges after removing a rectangular pulse with an amplitude of $20 \mathrm{~V}$ and a duration of $300 \mathrm{~ms}$ applied to the LC cells without Ag films (a), with the unannealed $(b)$ and the annealed $(c)$ Ag film at one interface. 
density was less and equaled $5,5 \times 10^{15} \mathrm{~cm}^{-3}$. In the cell without $\mathrm{Ag}$ films ion density was equaled to $0,23 \times 10^{15} \mathrm{~cm}^{-3}$. The presence of granular silver film at the interface of the LC cells led to the generation of additional ions. Additional ions in the LC cells with such structures may also arise as a result of a disengagement of ions from the surface of the granular Ag film. Thus, the morphology change in the granular silver films after annealing affected both the orientation of the LC molecules and the ion density in the LC cell. Increasing the charge carriers in the LC cell with the annealed Ag film can result from the enhancement of electron emission from the surface of Ag/ a-C:H/ITO thin multilayer films by applying constant electric field. We suppose that the presence of Ag nanoparticles on the surface of multilayer structure may result in the reduction of electron work function that facilitates electron emission.

To show the effect of the interaction of granular silver films with liquid crystals, we compared the extinction spectra of these films on glass substrates in structures with a-C:H/ ITO and in the LC cells. The measured optical density $D$ depends on the extinction cross section, which is the sum of the absorption and scattering cross sections. In our case, the scattering can be neglected, since the size of the silver granules is much less than $100 \mathrm{~nm}$ [35]. Only one peak in the absorption spectra was observed due to the use of non-polarized light beam with a wave vector always perpendicular to the substrate. The plasmonic peak in the spectra of metal nanoparticles depends on their form and size $[35 ; 36]$ as well as the distance between nanoparticles [37]. The extinction spectra of the granulated silver film, which characterize its plasmon properties, are shown in fig. 5.

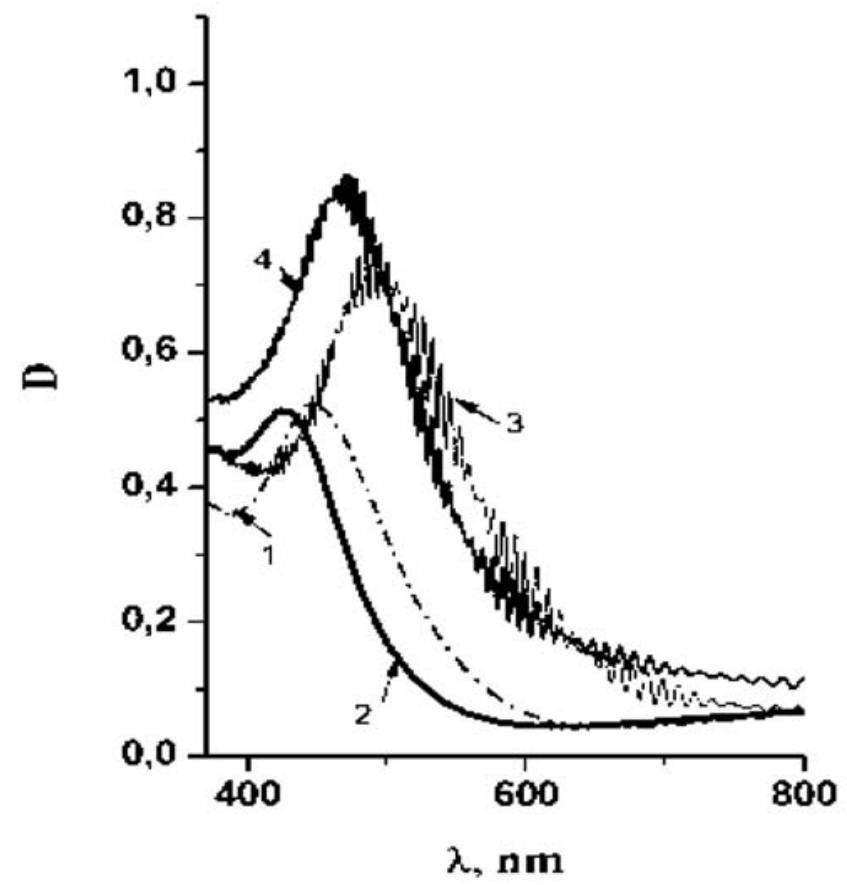

Fig. 5. The absorbance spectra of the granular silver films on the top of ITO/a-C:H thin multilayer films before $(1,3)$ and after annealing $(2,4)$ at $200^{\circ} \mathrm{C}$ on glass substrates and at the interface in LC cells. 
The comparison of the extinction spectra 1 and 2 in fig. 5 has shown the blue shift of the absorption band peak after annealing. The value of blue shift was about $16 \mathrm{~nm}$. We can conclude that both the decrease of the granules dimension and increase of the distance between them lead to the blue shift after annealing as other conditions do not change.

The liquid crystal is transparent in the visible region [38]. Thus, observed in the absorption spectra 3 and 4 in fig. 5 peaks are associated only with the localized surface plasmons in granular silver films. The red shift of plasmonic peak was observed in the LC cells spectra for both annealed and unannealed Ag films at the interface. The oscillations in the spectral curves appeared due to the interference in LC layer. The red shift values in the absorption spectra of granular silver films in LC cells were approximately the same for annealed and unannealed $\mathrm{Ag}$ films and equal to $45 \mathrm{~nm}$ comparing with the films on a glass substrate. Moreover, the peak intensity increased almost about 1.6 times for the annealed Ag film and 1,4 times for the unannealed film. The data of a wavelength and optical density of the localized plasmon excitation peak of the LC cells are listed in Table 1 . The peak intensity was bigger for the annealed Ag film at the interface with LC (fig. 5, curve 4). The absorption cross-section of metal nanoparticles depends on refractive index of surrounding media. Its increasing results in the red shift of the plasmonic peak and influences on the maximum absorption $[35 ; 36]$. The changes observed in the spectra 3 and 4 in fig. 5 are related to the change in the refraction index of LC at the interface with the Ag films.

Table 1.

The parameters of the absorption spectra of unannealed and annealed granular silver films on glass substrates covered with thin films of a-C:H/ITO and at the interface in LC cells.

\begin{tabular}{|c|c|c|c|c|}
\hline \multirow{2}{*}{$\begin{array}{c}\text { Granular } \\
\text { silver film }\end{array}$} & \multicolumn{2}{|c|}{ Wavelength of peak, nm } & \multicolumn{2}{c|}{ Optical density in maximum } \\
\cline { 2 - 5 } & On glass substrate & In LC cell & On glass substrate & In LC cell \\
\hline Unannealed & 447 & 492 & 0,52 & 0,72 \\
\hline Annealed & 425 & 470 & 0,51 & 0,82 \\
\hline
\end{tabular}

\section{Conclusion}

We have studied the change in the structure and plasmonic properties of granular silver films deposited by thermal evaporation in vacuum and then annealed at $200^{\circ} \mathrm{C}$. These Ag films were formed on a surface of a-C:H thin films deposited in glow discharge plasma which are aligned LC molecules planar. It has been shown by statistical analyses of SEM images that annealing the granular silver film on glass substrate covered with a-C:H/ITO films leads to the spheroid form of Ag nanoparticles with the average diameter of $\sim 30 \mathrm{~nm}$ and increase of the area of channels between them. It has been shown the impact of granular Ag films at the interface of LC cells on the molecules orientation by the studies of the transmission of LC cells in dependence on the applied voltage and the calculations of the phase retardation and the pretilt angle of the molecules. The pretilt angel of LC molecules was about $51^{\circ}$ before annealing film and decreased to $7^{\circ}$ after that. It has been founded the density of ion impurities in the LC cell with the annealed granular silver film at the interface in LC cells was three times 
higher than in the case of the unannealed film by measurement of the diffuse current of charges. We have studied the extinction spectra of the granulated silver film and observed that the intensity of plasmonic peak and its red shift in the absorption spectra of granular silver films at the interface in the LC cell depend on the LC molecules alignment on nanoparticles surface. The obtained results contribute to gain a more thorough understanding of the interaction between metallic nanostructured surfaces and liquid crystals for the development of optical device technology based on them.

\section{REFERENCES}

1. Franklin D., Chen Y., Vazquez-Guardado A., Modak S., Boroumand J., Xu D., Wu S.-T., Chand D. [Polarization-independent actively tunable colour generation on imprinted plasmonic surfaces]. In: Nature Communication, 2015, vol. 6, P. 7337 (1-8).

2. Si G., Zhao Y., Leong E.S.P, Liu Y.J. [Liquid-Crystal-Enabled Active Plasmonics: A Review]. In: Materials, 2014, vol. 7, pp. 1296-1317.

3. Zhang Y., Liu Q., Mundoor H., Yuan Y., Smalyukh I.I. [Metal Nanoparticle Dispersion, Alignment, and Assembly in Nematic Liquid Crystals for Applications in Switchable Plasmonic Color Filters and E-Polarizers]. In: ACS Nano, 2015, vol. 9, pp. 3097-3108.

4. Kamei T., Moritake H., Utsumi Y. [Microwave and Light-Wave Measurements for NematicLiquid-Crystal-Loaded Phase Shifter Using Coplanar Waveguide with Floating Electrode]. In: Japanese Journal of Applied Physics, 2010, vol. 49, P. 01 AF03 (1-6).

5. Goelden F., Gaebler A., Goebel M., Manabe A., Mueller S., Jakoby R. [Tunable liquid crystal phase shifter for microwave frequencies]. In: Electronic Letters, 2009, vol. 45, pp. 686-687.

6. Weil C., Muller St., Scheele P., Best P., Lussem G., Jakoby R. [Highly-anisotropic liquid-crystal mixtures for tunable microwave devices]. In: Electronic. Letters, 2003, vol. 39, pp. 1732-1734.

7. Blinov L.M. Structure and properties of liquid crystals. New York, Springer Science \& Business Media, 2011. 439 p.

8. Willman E., Seddon L., Osman M., Bulak A., James R., Day S.E., Fernandez F.A. [Liquid crystal alignment induced by micron-scale patterned surfaces]. In: Physical Review E, 2014, vol. 89, P. 052501 (1-7).

9. Yi Y., Nakata M., Martin A.R., Clark N.A. [Alignment of liquid crystals by topographically patterned polymer films prepared by nanoimprint lithography]. In: Applied Physics Letters, 2007, vol. 90, P. 163510 (1-3).

10. Silvestre N.M., Romero-Enrique J.M., Telo da Gama M.M. [Nematic liquid crystals on sinusoidal channels: the zigzag instability]. In: Journal of Physics-Condensed Matter, 2017, vol. 29, P. 014004 (1-6).

11. Rojas-Gymez Y.A., Romero-Enrique J.M., Silvestre N.M., Telo da Gama M.M. [Patterninduced anchoring transitions in nematic liquid crystals]. In: Journal of Physics-Condensed Matter, 2017, vol. 29, P. 064002 (1-14).

12. Amosova L.P. [How the deposition conditions of films of the oxides of semiconductors and metals affect the orientation of liquid crystals]. In: Journal of Optical Technology, 2013, vol. 80, pp. 179-186.

13. Konshina E.A. [Production methods and properties of liquid-crystal-orienting layers based on amorphous carbon]. In: Journal of Optical Technology, 2011, vol. 78, pp. 210-217.

14. Garbovskiy Y., Reisman L., Celinski Z, Camley R.E., Glushchenko A. [Metallic surfaces as alignment layers for nondisplay applications of liquid crystals]. In: Applied Physics Letters, 2011, vol. 98, P. $073301(1-3)$. 
15. Sanda P.N, Dove D.B., Ong H.L. [Role of surface bonding on liquid-crystal alignment at metal-surfaces]. In: Physics Review A, 1989, vol. 39, pp. 2653-2658.

16. Lo K.Y., Huang C.Y., Chu T.H., Hsu C.J., Lin C.H., Fuh A.Y.G. [Variation of nematic liquid crystal on a silver surface]. In: Journal of Optics A: Pure and Applied Optics, 2006, vol. 8, pp. 501-506.

17. Armitage D. [Alignment of liquid-crystal on a polarizing metal-film]. In: Applied Physics Letters, 1990, vol. 56, P. 1723 (1-2).

18. Ong H.L., Hurd A.J., Meyer R.B. [Alignment of nematic liquid-crystals by inhomogeneous surfaces]. In: Journal of Applied Physics, 1985, vol. 57, pp. 186-192.

19. Garbovskiy Y. [Ion capturing/ion releasing films and nanoparticles in liquid crystal devices]. In: Applied Physics Letters, 2017, vol. 110, P. 041103 (1-5).

20. Garbovskiy Y. [Electrical properties of liquid crystal nano-colloids analysed from perspectives of the ionic purity of nano-dopants]. In: Liquid Crystals, 2016, vol. 43, pp. 648-653.

21. Garbovskiy Y., Glushchenko I. [Nano-Objects and Ions in Liquid Crystals: Ion Trapping Effect and Related Phenomena]. In: Crystals, 2015, vol. 5, pp. 501-533.

22. Prasad S.K., Kumar M.V., Shilpa T., Yelamaggad C.V. [Enhancement of electrical conductivity, dielectric anisotropy and director relaxation frequency in composites of gold nanoparticle and a weakly polar nematic liquid crystal]. In: RSC Advances, 2014, vol. 4, pp. 4453-4462.

23. Prasad S.K., Sandhya K.L., Nair G.G., Hiremath U.S., Yelamaggad C.V., Sampath S. [Electrical conductivity and dielectric constant measurements of liquid crystal-gold nanoparticle composites]. In: Liquid Crystals, 2006, vol. 33, pp. 1121-1125.

24. Dhar R., Mishra M., Kumar S. [Effect of dispersed colloidal gold nanoparticles on the electrical properties of a columnar discotic liquid crystal]. In: RSC Advances, 2014, vol. 4, pp. 62404-62412.

25. Kamaliya B., Kumar M.V., Yelamaggad C.V., Prasad S.K. [Enhancement of electrical conductivity of a liquid crystal-gold nanoparticle composite by a gel network of aerosil particles]. In: Applied Physics Letters, 2015, vol. 106, P. 083110 (1-5).

26. Singh U.B., Dhar R., Dabrowski R., Pandey M.B. [Influence of low concentration silver nanoparticles on the electrical and electro-optical parameters of nematic liquid crystals]. In: Liquid Crystals, 2013, vol. 40, pp. 774-782.

27. Neeraj, Raina K.K. [Nickel nanoparticles doped ferroelectric liquid crystal composites]. In: Optical Materials, 2013, vol. 35, pp. 531-535.

28. Geis M.W., Bos P.J., Liberman V., Rothschild M. [Broadband optical switch based on liquid crystal dynamic scattering]. In: Optics Express, 2016, vol. 24, pp. 13812-13823.

29. Guralnik I.R., Samagin S.A. [Electrophysics of a modal multichannel liquid-crystal wavefront corrector]. In: Quantum Electronics, 2002, vol. 32, pp. 362-366.

30. Barton Y., Kal'nin A.A. [Liquid-crystal diode generator of low-frequency oscillations]. In: Technical Physics, 1998, vol. 43, pp. 112-113.

31. Leonov N.B., Gladskikh I.A., Polishchuk V.A., Vartanyan T.A. [Evolution of the optical properties and morphology of thin metal films during growth and annealing]. In: Optics and Spectroscopy, 2015, vol. 119, pp. 450-455.

32. Konshina E.A., Fedorov M.A., Amosova L.P. [Determining the director tilt and phase lag of liquid-crystal cells by optical methods]. In: Journal of Optical Technology, 2006, vol. 73, pp. 830-833.

33. Shcherbinin D.P., Konshina E.A, Solodkov D.E. [The effect of CdSe/ZnS quantum dots on the rotational viscosity and charge carrier concentration of a nematic liquid crystal]. In: Technical Physical Letters, 2015, vol. 41, pp. 781-783.

34. Shcherbinin D.P., Konshina E.A., Polischuk V.A. [Influence of surface properties on the structure of granular silver films and excitation of localized plasmons]. In: Optics and Spectroscopy, 2016, vol. 120, pp. 622-627. 
35. Noguez C. [Surface Plasmons on Metal Nanoparticles: The Influence of Shape and Physical Environment]. In: The Journal of Physical Chemistry C, 2017, vol. 10, pp. 3806-3819.

36. Muskens O.L., Billaud P., Broyer M., Del Fatti N., Vallŭe F. [Optical extinction spectrum of a single metal nanoparticle: Quantitative characterization of a particle and of its local environment]. In: Physical Review B, 2008, vol. 78, P. 205410 (1-9).

37. Su K.H., Wei Q.H., Zhang X., Mock J.J., Smith D.R., Schultz S. [Interparticle coupling effects on plasmon resonances of nanogold particles]. In: Nano Letters, 2003, vol. 3, pp. 1087-1090.

38. Kurochkina M.A., Shcherbinin D.P., Konshina E.A. [Spectral and dielectric properties of a nematic liquid crystal doped semiconductor quantum dots CdSe/ZnS]. In: Proceedings of SPIE, 2015, vol. 9519, P. 95190Z (1-5).

\section{ИНФОРМАЦИЯ ОБ АВТОРАХ}

Коншина Елена Анатольевна - доктор физико-математических наук, ведущий научный сотрудник Центра информационных оптических технологий Санкт-Петербургского национального исследовательского университета информационных технологий, механики и оптики;

e-mail: eakonshina@mail.ru;

Щербинин Дмитрий Павлович - инженер Центра информационных оптических технологий Санкт-Петербургского национального исследовательского университета информационных технологий, механики и оптики;

e-mail: shcherbinin.dmitrij@gmail.com

\section{INFORMATION ABOUT THE AUTHORS}

Elena A. Konshina- Doctor in Physico-mathematics science, leading researcher of the Center for Information Optical Technologies, Saint-Petersburg National Research University of Information Technologies, Mechanics and Optics;

e-mail: eakonshina@mail.ru;

Dmitrii P. Shcherbinin - engineer of the Center for Information Optical Technologies, SaintPetersburg National Research University of Information Technologies, Mechanics and Optics; e-mail: shcherbinin.dmitrij@gmail.com

\section{ПРАВИЛЬНАЯ ССЫЛКА НА СТАТЬЮ}

Konshina E.A., Shcherbinin D.P. Effect of granular silver films morphology on the molecules orientation and ion contamination of nematic liquid crystal // Вестник Московского государственного областного университета. Серия: Физика-Математика. 2017. № 4. С. 103-113. DOI: 10.18384/2310-7251-2017-4-103-113

\section{FOR CITATION}

Konshina E.A., Shcherbinin D.P. Effect of granular silver films morphology on molecule orientation and ion contamination of nematic liquid crystal. In: Bulletin of Moscow Region State University. Series: Physics and Mathematics, 2017. no. 4. pp. 103-113.

DOI: 10.18384/2310-7251-2017-4-103-113 